\title{
Article
}

\section{Well-Being Impact on Banking Systems}

\author{
Iulia Cristina Iuga $1, *(1)$ and Larisa-Loredana Dragolea ${ }^{2}$ (1) \\ 1 Department of Finance and Accounting, “1 Decembrie 1918” University of Alba Iulia, \\ 510009 Alba Iulia, Romania \\ 2 Department of Business Administration, "1 Decembrie 1918" University of Alba Iulia, \\ 510009 Alba Iulia, Romania; larisadragolea@uab.ro \\ * Correspondence: iuga_iulia@yahoo.com
}

Citation: Iuga, Iulia Cristina, and Larisa-Loredana Dragolea. 2021. Well-Being Impact on Banking Systems. Journal of Risk and Financial Management 14: 134. https:// doi.org/10.3390/jrfm14030134

Academic Editor: Yong (Aaron) Tan

Received: 16 February 2021

Accepted: 18 March 2021

Published: 21 March 2021

Publisher's Note: MDPI stays neutral with regard to jurisdictional claims in published maps and institutional affiliations.

Copyright: (c) 2021 by the authors. Licensee MDPI, Basel, Switzerland. This article is an open access article distributed under the terms and conditions of the Creative Commons Attribution (CC BY) license (https:// creativecommons.org/licenses/by/ $4.0 /)$.

\begin{abstract}
The present research focuses on the influence of the well-being indicators, more specifically, the indicators reflecting the life quality on the banking systems evolution from the EU member states. The study offers a unique approach to comparing the two country groups: the eurozone countries and the EU noneuro countries during the 2008-2019 period. The model is estimated with the help of the OLS method by using panel data. The study aims to identify which life quality indicators significantly influence the EU member states' banking systems evolution and develop models dividing the countries into two groups. Our conclusions show that, among all the determinant factors analysed in this study, household consumption and internet users strongly influence all EU countries' banking systems.
\end{abstract}

Keywords: well-being; quality of life indicators; banking systems; regression analysis; eurozone countries; noneuro countries

\section{Introduction}

The present research analyses the impact of representative well-being factors, namely mortgage, rent, utility bills or hire purchase arrears, inability to face unexpected financial expenses, income insecurity, household consumption, unemployment rate, and internet users, on banking system evolution, expressed as the number of commercial bank branches per 100,000 adults. The banking system evolution has a major influence on the population's well-being reflecting in the manner of lending for the banks, as well as for the population. The relation between the banking system and population is a win-win partnership, as observed by recent studies. The access to financial services and products, the existence of a bank account, and a credit line are well-being influence factors (Muir et al. 2017). The financial stability of the states is equally supported by banks and population. In Romania, e.g., the population sector is from 2012 until the present time in the position of net creditor of the banking system (BNR Report 2020). Nowadays, when digitisation reaches a peak, many economic entities must reconsider their strategy to survive. By diversifying services, the banking units also adapted to the new trend and have developed financial services in accordance with the sudden evolution generated by covid-19 pandemic.

The banking system development is currently measured in the number of bank branches. Many banks reduce the number of branches and develop on other channels (e.g., internet banking). These channels are also connected to population's well-being because population is one of the significant targets, of special importance in the banking operations.

Concerning wellbeing, as a whole, the population's welfare is becoming an increasingly present preoccupation among European policies. The banking system invariably brings many changes through its complexity and omnipresence in the population's life and activity. It exercises direct or indirect and visible or invisible influences on the activity of every person category. The population's activity is likely to permanently intersect with 
elements belonging to the banking sector, to a greater or lesser extent. Practitioners understand and theoreticians analyse and present the importance of management and approach in every aspect of banking, filtered through the wellbeing state of insurance needed by the beneficiary mainly, and the population in general.

The pandemic crisis compared to the period crises shows a future impact on all banks (Aldasoro et al. 2020). By slowing the global economy, the pandemic has already impacted the banking sector (Drehmann et al. 2020). The financial recovery of these units depends on capitalisation coming from the population, in direct relation with the well-being level. The analysed aspects verify how the population's well-being depends on the factors highlighted in our research.

Aiming to obtain relevant valid data in the present study, the authors considered it important to perform the research by analysing a set of indicators agreed at the EU level, in order to obtain results possible to be compared for all EU member states, which are the subject of the research.

The study of the correlation between banking systems and well-being in the period between the two major crises (the crisis in 2008, with a certain level of predictability among the specialists, and the pandemic crisis starting in 2020, impossible to be anticipated by any method or set of data) can generate important hypotheses for the future behaviour of the banking system in other possible crises situations.

The downward trend of the number of commercial bank branches per 100,000 adults in 2008-2019 can be the result of various factors. We examine these factors in our studies, trying to answer the following questions: Which factors reflecting the life quality have a major influence on the number of commercial bank branches per 100,000 adults in the EU countries? What are the differences between the two groups of EU countries (eurozone and noneuro)? Which group resembles more the major group EU-ALL? The comparison between the two groups of countries is useful and instructive not only for a better understanding of the economic and social contexts beyond the well-being related phenomena, but also because past experiences can offer answers to our questions on the present events.

The article aims at identifying the influence level of the well-being factors (in the component of economic well-being) on the banking system in the EU countries. The article's added value resides in identifying if this influence is significant and if the euro currency creates advantages to the adopting countries. Moreover, three of the well-being factors we use are macroeconomic indicators (unemployment rate; household consumption as per cent of GDP; Internet users, per cent of the population). Thus, we can observe at the same time if they have a stronger influence on the dependent variable (number of commercial bank branches per 100,000 adults). The article aims to create models for EU-ALL (all 27 member states), followed by classification in two groups: eurozone countries and countries using a national currency (noneuro countries). We also aim to analyse the influence of well-being factors on the number of commercial bank branches per 100,000 adults. We intend to identify the indicators that significantly influence the number of commercial bank branches for the eurozone countries and the EU noneuro countries and the correlations' intensity. The final part intends to give answers to the questions mentioned above. Our study's selected countries are EU member states: 27 countries for the EU-ALL model, including 19 eurozone countries and eight noneuro countries.

The present study intends to cover a research deficit, offering a solid empirical investigation based on well-established theoretical considerations. We identify the macroeconomic factors determining the number of commercial bank branches per 100,000 adults using the ordinary least square (OLS) method for panel data.

The study offers a unique approach to comparing the two country groups: the eurozone countries and the EU noneuro countries in the period of the two major crises of the 21st century: the economic crisis in 2008 and the pandemic crisis in 2020.

Our study includes all the EU member states in the period between 2008 and 2019. The second section of the study is dedicated to the literature review. In contrast, the third section describes the data and the research methodology, meaning the variables, the empirical 
results of our model, and their comparison to other studies, followed by conclusions in the last section.

\section{Literature Review}

The concept of "well-being" was used in the field of international relations without an exact acceptance of the term, but to describe reaching a state of well-being. Comerton-Forde et al. (2018) defined financial well-being as the level to which people perceive and have financial results to fulfil their financial duties, financial freedom to make choices allowing them to enjoy life, the control over their finances, and financial security (in the present time, in the future and in possible unfavourable situations). The researchers agree on the idea that the final aim of the economic policies is to maximize population well-being. A financial crisis has the power of shocking a well-being system, placing considerable burdens on economies and individuals. Many studies research the channels through which the crises impact the real economy by perturbing the credits and leading to a loss of wealth and a decrease in production (Bernanke 1983; Cecchetti et al. 2009), with a direct impact on the evolution of the number of bank branches. Any lack of trust created by the financial crises generate a higher incertitude of the bank system, with a negative impact on consumption and investment levels, in general, and on individuals' well-being, in particular (Montagnoli and Moro 2014).

Research studies show that (Frey and Stutzer 2002; MacKerron 2012) well-being indicators are correlated with micro- and macroeconomic factors (such as income, statute of the workplace, and unemployment rate). Theories evaluated the point to which well-being is considered an important indicator for the illustration of economic welfare for a zone or a country, implicitly in the bank field.

Usually, indicators are classified as objective indicators and subjective indicators. The objective situations and the subjective perceptions contribute in the same time to the determination of an individual's well-being (Eurostat-European Statistics 2020).

Some authors consider that it is necessary to focus on the subjective factors (Diener et al. 2003; Tonzer 2017), while other authors give more credit to the objective elements. A clear delimitation between the objective and the subjective parts of the indicator life cannot be established (i.e., income is an objective indicator, but satisfaction is a subjective indicator). Prawitz proposed a scale for measuring the perceptions of the financial well-being and the stress it generates (Prawitz et al. 2006). Stiglitz et al. (2009) clarified the fact that both aspects are important, and their measuring must be statistical and centralised.

Even if the individuals have resources, it can happen that they are not properly materialised. Therefore, it is possible that life quality, including well-being, does not reach the desired level, so, individual behaviour is not an indicator of well-being. Other studies underline the idea of inner well-being and external well-being, also labelled human well-being and social well-being. The factors we analyse in our study fall in the category of external factors, as components offering a general perception of life quality. It is considered (Alatartseva and Barysheva 2016) that the external factors integrate a set of four common characteristics, as follows: human life according to the social norms; everyone's understanding of the utility and the existence of abilities for gaining what is necessary to everyone; an individual's ability to reach his or her potential; the formation of a community and its empowerment for the fulfilment of the three previously mentioned factors.

\subsection{Well-Being and Banking Systems}

The banking system never presented periods of long stability or perfect predictable periods, because it is a dynamic sector, but the two major crises we discuss in this article (the crisis in 2008 and the crises in 2020 in progress) produced, similar to other sectors, substantial modifications in the normal evolution of the sector. The effects of the crisis in 2008 were negative and very persistent in all countries; the areas with concentrated 
financial centres suffered more important losses (Montagnoli and Moro 2018), with longterm major effects. These banking crises transmit to the population a state of uncertainty (Dow 2012), decrease the trust in the banking system and especially the loan accession.

Uncertainty and financial crisis are major costs for the economy (Bloom et al. 2012). The shock produced by a financial crisis puts burdens on the economy as well as on the population (Montagnoli and Moro 2018), diminishing the quality of life. Usually, the indicators of the well-being are associated with micro- and macroeconomic factors (incomes, situation on the labour market, and unemployment) (Frey and Stutzer 2000; MacKerron 2012), and are the first to be affected by the economic crisis. Bloom (2009); Bloom et al. (2012); Gilchrist et al. (2014) presented in their studies the major effect of the degree of uncertainty during economic recession from a macroeconomic perspective and concluded that economic uncertainty does not develop according to clearly established and predictable cycles; instead, it suddenly grows during recessions and the impact of uncertainty on the economy varies in time.

\subsection{Debt and Banking Systems}

The situation of debts or arrears, mortgages, rents and utilities payments differ from one state to another, depending on the citizens' established behaviour in each country. Normally, this type of arrears is paid monthly, a situation in which each citizen's budget is predefined and the arrears are at the top of the monthly payments. Still, the periods of fluctuation can destabilize personal budgets and banking systems can support these situations. The impossibility of payment leads to overdue mortgages (overdue payments for a period longer than 90 days). The situation of debts/arrears differs depending on the country, as constantly indicated by Eurostat reports. Persons living in families with children who depend on the parents' income, are twice as likely to be in the situation of not being able to pay bank loans (Eurostat-European Statistics 2020). The correlation between debt/arrears (mortgage or rent, utility bills or hire purchase) and banks or banking systems varies from one country to another and is powerfully influenced by the percentage of the population living in personal dwellings. Regarding the home ownership rate, one of the highest percentages in the world and Europe is Romania's $96.4 \%$, followed by Slovakia with $91.3 \%$, Croatia with $90.1 \%$, and Lithuania with $89.9 \%$ (Iuga and Mihalciuc 2020). The population manifests a permanent fear related to the evolution of the economic situation, especially due to the uncertainty after a major crisis, as it was the crisis in 2008 (Gathergood 2012). Despite this fear, some specialists underline (Zingales 2011) the fact that there is a strong relation between the trust of the depositors in the banking system and the ability of the banks to maintain the safety of savings.

Reinhart and Rogoff (Reinhart and Rogoff 2011) show that a banking crisis is affected by two aspects: closing, fusion or public takeover of banking institutions and execution of banking activities with governmental assistance.

As highlighted by several authors (Barrell et al. 2006), the influence of economic crises on consumption should not be disregarded, especially in the presence of an important leverage as bank loans accessed for paying debts as mortgages, rent, and utilities.

\subsection{Wealth (Inability to Face Unexpected Financial Expenses) and Banking Systems}

To the level of all EU member states, the latest modifications for the population, especially in households, have affected the entire financial decisional process (KowalczykRólczyńska and Rólczyński 2020). The financial security of each family resides in the efficient management of resources and their allocation in the decisions of consumption, loan, saving, investment, and risk management. Unexpected or nonprogrammed expenses can destabilize the financial security of a household. Kapoor et al. presents three terms for satisfaction of the individual needs of the population: short-term (maximum one year), medium-term (a period of two to five years), long-term (more than five years) (Kapoor et al. 2007). The consumption decision is one of the most important decisions and it is in direct relation with the income. When consumption exceeds income, the population 
will reach a certain degree of indebtedness or inability to cover financial expenses, which is a reason for banking systems, through their institutions, to represent an escape from indebtedness. According to the specialists (Katona 1975), the degree of indebtedness of the population is caused by a low income unable to cover the basic needs, a high income correlated with high expenses, and a lack of the intention to save (disregarding the income level).

The impossibility to cover unforeseen financial obligations seriously affects the economic stability of the population, who can become vulnerable in periods of financial crisis.

Therefore, it is easy to highlight that the profitability of banks is influenced not only by internal decisions, like management decisions, but also by external factors, like change in the macroeconomic environment, more exactly the weak saving trend of the population, the accumulation of debts and, implicitly, the use of the banking services (Staikouras and Wood 2004). The loans for households represent one of the three basic loan services influencing the evolution of the banking systems, together with business loans and the collection of taxes and commissions (Smith et al. 2003).

\subsection{Income Insecurity and Banking Systems}

The present accentuated transition stage on the labour market is in direct connection with the level of income insecurity. This fact is alarming for the activity and the profitability of bank branches, especially in the context of anti-covid-19 pandemic measures in the 2020 in many European states, which manifested in a postponement of loan rates for the population. Banks can be affected less by future economic crisis, even in conditions of decrease of income from interest, with maintenance of the consumption level. Still, the reality is that the insecurity of income determines a large part of the population to reduce the consumption level, especially when the fluctuation on the labour market does not allow any type of prediction of the evolution of income and future financial availabilities for some categories of population. According to Eurostat (Eurostat Statistical Reports 2017), the typology of the transactions on the labour market with a direct and indirect impact on the banking system is the transition to unemployment, the transition to total inactivity (retirement), the transition to employment, the transition to a permanent workplace, and the transition to a temporary workplace.

The security of the banking and credit system is a component in the financial security of the state (Cauia 2020). The income insecurity caused by the loss of workplace seriously affects the security degree of the income, generating an immediate insecurity, manifested as negative influence in relation to banking systems. We mention that the financial state is reflected in the assessment of creditworthiness by banks, meaning the capacity to pay back a loan. The monitoring of the probability for a credit risk due to the income insecurity caused by the fluctuations on the labour market is not a banal and easy activity; this activity offers a perspective for the complex relations between the income insecurity indicator and banking systems (Chunguang et al. 2019).

\subsection{Factors Impacting the Evolution of the Bank Branches Indicator}

Existing studies using the number of bank branches as dependent variable show that this factor is positively associated in the market with bank profitability caused by the existence of the interest-bearing assets (Hannan and Hanweck 2008). The literature dedicated the number of bank branches is poor. We can mention the contribution of Avery et al. (1999), Damar (2007) and Barros (1999); all of them showed that the number of bank branches can influence, to a local level, various indicators, among which is the field of activity. The correlations between the number of bank branches and well-being indicators have not been identified, creating the possibility for our study to bring a new contribution.

The system of banking distribution (measured by number of bank branches) constantly passes through a process of fast change (Moutinho and Phillips 2002). The efficacy of the activity of banking systems is directly influenced by using efficient management practices. The banking system presents fluctuations in the volume of the operations, the typology 
of services, employment and, implicitly, the number of branches, which varies from a period to another. In the past, there was a national level policy imposing restrictions for the number of bank branches in a certain areal, but these limits do not operate anymore, because the involvement of the state in the activity of the banks, such as the number of bank branches, is considered unsuitable. This situation is general for most European states; the average is 37 bank branches per 100,000 adults (Popa 2019). The calculation of bank branches' efficiency is necessary for establishing the optimum number of bank branches in an area. Cost minimisation is an important factor that should be taken into consideration for the numerical distribution of bank branches, but efficiency is the primary factor for an efficient decision in bank management (Berger et al. 1997).

Many specialists consider that the banking industry is one of the most researched fields of activity (Paradi and Zhu 2013). Personnel efficiency mostly influences the activity of bank branches, like quality and profitability (Schaffnit et al. 1997). Data envelopment analysis (DEA) is already a large-scale method for identification of inefficient decisions in an organisation (Vassiloglou and Giokas 1990). The DEA model was developed for the establishment of strategic orientations and the foundation of operational decisions for maximum performance (Zenios et al. 1999). This model can offer reporting criteria for the relative efficacy of bank branches; strategic managerial orientations; isolation of external factors influence on the efficacy of bank branches. The use of this efficacy and profitability matrix allows the illustration of the performance profile of a banking entity (Camanho and Dyson 1999) and is a useful instrument for the bank management by redistributing resources between bank branches in order to obtain a superior level of efficacy (Oral and Yolalan 1990).

Various studies analysed the impact of enlargement of the bank branches network on the banking system (Bernini and Brighi 2018; Cvetkoska and Savić 2017; Kassani et al. 2018); the results highlighted the fact that a bank unit with a diverse offer justifies the costs by enlarging the territorial bank network, but, in the case of quantitatively limited services, the enlargement has a negative effect on profitability.

In conclusion, the main factors impacting the positive evolution of the indicator for the increase of bank branches are service quality, technology, innovation, and employee involvement (Chai et al. 2016). The bank can improve its performance by increasing the level of technological use and by creative innovation (Neely et al. 2000).

\subsection{Macroeconomics and Internet Infrastructure Indicators and Banking Systems}

Macroeconomic indicators show the present state of a national economy; their analysis can also show the reaction of the economy to the interaction with various external factors. The conditions determined by unfavourable factors are a signal for the decisive factors that the banking system requires improvement (Batishcheva et al. 2017).

The evaluation of macroeconomic indicators' impact on the banking system can be performed by using a series of methods, consisting of the elaboration of methodologies or analyses (Mamonov 2011).

Internet utilisation rates have had an unprecedented dynamic during the last years. The opportunities offered by the internet are promising, especially for the optimisation of managerial decisions, the adoption of efficient risk management and operational efficacy, innovation capacity increase, and improved client management (Benvenuto et al. 2020).

Household internet access positively influences banking activity and, implicitly, banking systems because potential clients are easier to approach, and clients can benefit from the advantages of internet banking. Technology is an engine for the development of banking activity (Al-Sharafi et al. 2017).

Household well-being also depends on free time and the possibility to make payments, open accounts, receive counselling or cash in in real time supports the increase of the value of this indicator and life quality. The new digital technologies accessed by the population almost with no limits and with reduced costs automate a significant part of the financial services, facilitate the creation of new and profitable banking products, portfolio advice, 
and payment systems (Vives 2017). It is important for banking organisations to use the best means to protect the clients' data in a context when clients avoid online transactions for fear of becoming victims of fraud (Pavlou et al. 2007).

If banking systems manage to assure clients of the protection of personal data an present and respect the security policy, they will also manage to attract, preserve and grow their portfolio of clients (Galati et al. 2017).

One of the macroeconomic factors acting as a force for bank loans is the unemployment rate (Berge and Boye 2007). The bank loans determined by this factor are usually nonperforming, questionable and problematic. A high unemployment rate is accompanied by a high rate of nonperforming loans. The lack of well-being, the burden of the debt, the loan rate, and the unemployment rate are the key elements at the base of the bank losses due to loans for households (Frøyland and Larsen 2002), with a direct effect on the evolution of banking systems. Pesola's study mentions that the financial vulnerability of households caused by the unemployment rate, the burden of debts, the macroeconomic shocks caused by the increase of GDP, and the real interest rate are decisive factors for bank losses (Pesola 2005).

Because online buyers are different from traditional buyers, banking services must include offers for both categories. The banks offering internet-banking services can evaluate the real importance of internet services for the evolution of banks (Lassar et al. 2005).

The internet seems to be the ideal environment to develop the relationship between the internet-using client and the bank. The savings generated for the bank and the speed of internet service justify the continuous increase of the services of online banking (Floh and Treiblmaier 2006). The major inconvenience is at the present time the difficulty to ensure the loyalty of online clients.

The advantages of a good relation between internet users and banks are, from the perspective of banks, as follows: diminishing the costs, gaining new clients, efficacy, and the possibility to improve the reputation among clients and potential clients (Jayawardhena and Foley 2000). Online banking services bring satisfaction to the clients and to the bank and are a contemporary reality (Raza et al. 2020).

Banks need to create a mechanism for the consolidation of trust in the online environment, in relation with the services they offer (Kaur and Arora 2020).

Banking users' expectations change together with the digitalisation of the banking systems and channels (Putica 2020). According to Bergendahl and Lindblom, digitalisation reduces the costs and the communication with the clients is transferred to the branches (Bergendahl and Lindblom 2007). Digitalisation does not create the social need of reducing the number of bank branches, because the services of assistance, advice and consultancy must be maintained to high standards, therefore implying a direct contact with bank representatives. Although around the year 2008 the banks competed to open new branches, this competition is no longer present nowadays. Still, a specific number of branches must exist in an area depending on the number of inhabitants (Nagorny 2020).

Considering the complexity and the range of the issues, from several factors influencing the evolution of the banking systems (measured as the number of commercial bank branches per 100,000 adults), we selected for our research the following indicators: mortgage or rent, utility bills or hire purchase, inability to face unexpected financial expenses, income insecurity, household consumption, unemployment rate, and internet users. The reason for our choice is the fact that influencing factors and dependent variable evolutions have significantly changed since 2008. Our study approaches the dependence and the impact of the above-mentioned six indicators on the banking systems in eurozone countries and noneuro countries. We have no knowledge of empirical studies offering a comparative analysis on the impact of these indicators on the banking systems of the eurozone countries and the EU countries using a national currency, in the period between the two major crises of the 21st century: 2008-2020.

Based on the main dimensions of the representative well-being factors (mortgage, rent, utility bills or hire purchase arrears, inability to face unexpected financial expenses, income 
insecurity, household consumption, unemployment rate, and internet users) resulting from the literature, the hypothesis of our research is presented as follows.

Research hypothesis $(\mathrm{H})$ : the increase of well-being indicators reflecting the quality of life (mortgage, rent, utility bills or hire purchase arrears, inability to face unexpected financial expenses, income insecurity, household consumption, unemployment rate and internet users) is associated with a downward trend in the banking systems evolution in the EU countries.

Therefore, we observe that, once several econometric issues are approached, the effect of the six indicators (mortgage, rent, utility bills or hire purchase arrears, inability to face unexpected financial expenses, income insecurity, household consumption, unemployment rate, and internet users) on the number of commercial bank branches per 100,000 adults becomes more robust, corroborating the predictions of the proposed theoretical model. We approach the issue of endogeneity and heterogeneity between countries related to the parameters of the model and the transversal dependencies.

Thus, our contribution to the empirical literature is twofold. Firstly, unlike previous studies, we do not use techniques for the estimation of panels in order to combine the average of the transversal section with all the subtleties of temporal dependence; we rather explore the dimension of the temporal series to obtain supplementary proofs based on the historic experience of each country in the sample, in order to detect the potential heterogeneity in the relation between the eurozone countries and the noneuro countries. Secondly, our econometric methodology is based on data and allows the selection of a statistic model best approximating the relation between the variables studied for a certain country and to evaluate the influence of the six indicators on the banking systems. The model is estimated with the help of the ordinary least square (OLS) method by using panel data. The authors considered the fixed effect estimation or the random effect estimation and performed corresponding tests to determine the best estimation method (Hausman test). Moreover, the authors tested if endogeneity exists because this matter must be considered in the estimation methodology.

\section{Research Methodology and Data}

To reach the objective of our research, we used several methodological approaches. The basis of the research was the content-cause analysis of the theoretical aspects and practical research. Referring to the theoretical aspects (presented in the previous section), we defined the macroeconomic indicators, the well-being indicators (quality of life, economic security) and the internet infrastructure indicator, which are included in the data base for analytical processing using econometric methods. All the indicators are components of the wellbeing indicator. Based on the analysis of a set of studies approaching several indicators, we decided to use the following indicators in their empirical research: mortgage, rent, utility bills or hire purchase arrears (Debt), inability to face unexpected financial expenses (Exp), income insecurity (Ins), household consumption (Hc), unemployment rate (Ur) and internet users (Int). All these indicators are in the category of the variables of influence.

A single currency offers several advantages: consumers have more opportunities and choices. The aim of the study is to identify the indicators influencing the greatest number of bank branches in the EU member states and to create models by separating the countries into two groups: eurozone countries and noneuro countries. The reason for the separation of countries into two groups is to observe if the single currency creates advantages compared to the national currencies of the noneuro countries. Proxies and expected relationship of all the variables are provided in Table 1 . The dependent variable is bank branches per 100,000 adults. We collected data from all 27 countries for the period 2008-2019 (i.e., between the two major crises: the economic crisis in 2008 and the pandemic crisis in 2020). We collected the data using the websites Eurostat and Theglobaleconomy.com. 
Table 1. Variables description.

\begin{tabular}{|c|c|c|c|}
\hline Category & Variables & Measurement & Expected Sign \\
\hline \multicolumn{4}{|c|}{ Independent variables } \\
\hline \multirow{6}{*}{$\begin{array}{l}\text { Well-being } \\
\text { indicators }\end{array}$} & Debt & Arrears: mortgage or rent, utility bills or hire purchase & - \\
\hline & Exp & Inability to face unexpected financial expenses & - \\
\hline & Ins & Income insecurity $\mathrm{r}$ & - \\
\hline & Hc & Household consumption as percent of GDP & $+/-$ \\
\hline & Ur & Unemployment rate & - \\
\hline & Int & Internet users, percent of population & - \\
\hline \multicolumn{4}{|c|}{ Dependent variable } \\
\hline $\begin{array}{l}\text { Bank branches } \\
\text { per } 100,000 \\
\text { adults }\end{array}$ & BB & $\begin{array}{l}\text { Number of commercial bank branches per 100,000 } \\
\text { adults }\end{array}$ & \\
\hline
\end{tabular}

Source: Authors' view.

As a first step, we briefly present a graphic of the dependable variable (bank branches per 100,000 adults; BB), as in Figures 1 and 2. As is possible to observe, the downward trend of the bank branches indicator registers in all countries (eurozone countries and countries using the national currency).



Figure 1. Bank branches per 100,000 adults in noneuro countries during 2008-2019.

For the period 2008-2019, we can observe a linear decrease in some countries (Croatia, Denmark, Hungary, Romania, and Sweden), while, for the rest of the countries, the decrease is not continuous, but followed by some small increase. Poland and the Czech Republic registered a small increase after the crisis in 2008, but the decrease reappears in 2014. In general, for the entire period, we observe a downward trend in all countries. Comparing Figures 1 and 2, we observe the same linear downward trend also for the eurozone countries. There is no difference in the evolution of this indicator for the countries using their national currency (considering the specificity of the currency and its management by the state authority) and the eurozone countries. Beginning in 2008, together with the decrease of the bank profitability in all countries, all banks tried to streamline their activity by reducing the number of employees and the number of bank branches. 


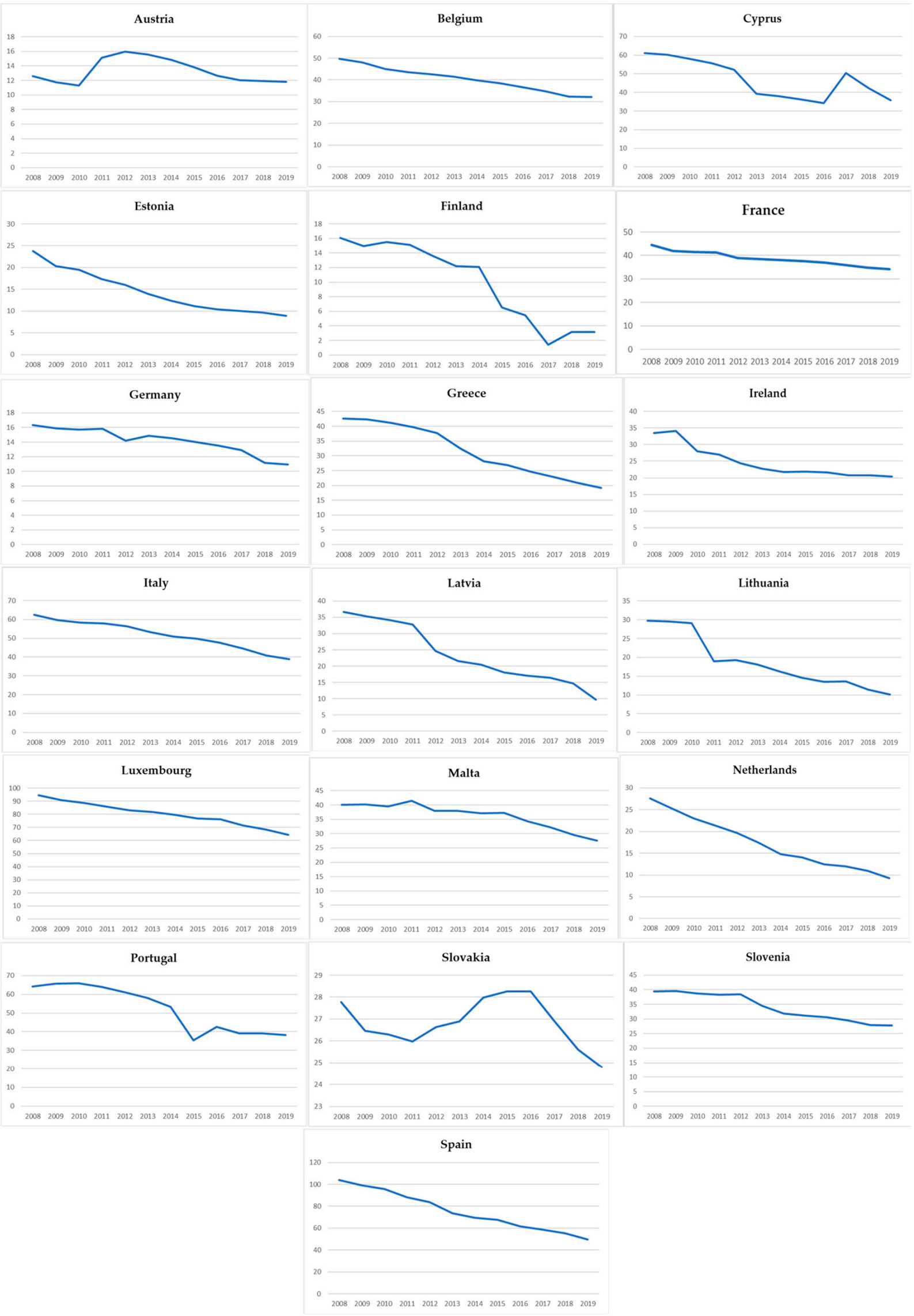

Figure 2. Bank branches per 100,000 adults (BB) in eurozone countries 2008-2019. 
Standard deviation is an indicator showing the distance between the values of a variable and their average (Table 2). The level of the dependent variable (bank branches per 100,000 adults) is approximately 33.53 bank branches per 100,000 adults for the period between the two crises (2008-2020). The noneuro members present a level of 31.57 for the indicator $\mathrm{BB}$, while the eurozone members present a higher level ( 34.22 bank branches per 100,000 adults). It is not difficult to observe the difference between the eurozone members and the noneuro members, for the indicator $\mathrm{BB}$ is significant and represents a good reason for a separate analysis of $\mathrm{BB}$ on these two subgroups in order to explain the variation. Finland registered in 2019 the lowest BB value in EU (3.13), while Luxembourg registered the highest value (64.49).

Table 2. Statistical values for BB depending on the groups of countries.

\begin{tabular}{ccccc}
\hline Group & Mean & Std. Dev. & Min. & Max. \\
\hline EU All & 33.53 & 19.70 & 1.43 & 103.75 \\
Euro countries & 34.22 & 21.00 & 1.43 & 103.75 \\
Noneuro countries & 29.57 & 16.26 & 14.19 & 92.17 \\
\hline
\end{tabular}

Source: authors' processing.

\subsection{The Regression Analysis}

We used regression analysis to estimate the relation between bank branches per 100,000 adults (BB) and well-being variables. This regression analysis helps us understanding the evolution of the dependent variable (BB) with the variation of one or more independent variables.

The empirical function is posed as follows:

$$
\mathrm{BB}=F(\text { Debt, Exp, Ins, Hc, Ur, Int) }
$$

We will create the models for EU-ALL (all 27 states) and further split the countries in two groups: eurozone countries and countries using the national currency (noneuro countries).

For the indicators BB, Debt, Exp, Ins and Ur, we observe that skewness is above 0, so our data have more extreme values on the right, with a distribution inclined to the left; $\mathrm{Hc}$ and Int present values under 0 , with extreme values on the left and a distribution inclined to the right (see Table 3). Most indicators, except for inability to face unexpected financial expenses and internet users, register values above 3 , belonging to a positive kurtosis with a pointed curve-leptokurtosis. The indicator of inability to face unexpected financial expenses, with a value of 2.79 , presents a platykurtic distribution. The indicators BB, Debt and $\mathrm{Hc}$, with values close to 3 , suggest a normal distribution of the mesokurtic type.

Table 3. Descriptive statistics of all EU member states (EU-ALL).

\begin{tabular}{cccccccc}
\hline & BB & Debt & Exp & Hc & Ins & Int & Ur \\
\hline Mean & 33.47043 & 13.78852 & 38.39105 & 54.68414 & 3.494136 & 74.47361 & 8.957284 \\
Median & 29.56000 & 10.55000 & 35.85000 & 54.68000 & 3.100000 & 75.93000 & 7.630000 \\
Maximum & 103.7500 & 49.30000 & 80.40000 & 70.77000 & 13.30000 & 98.25000 & 27.47000 \\
Minimum & 1.430000 & 2.400000 & 13.90000 & 29.49000 & 0.100000 & 32.42000 & 1.930000 \\
Std.Dev. & 19.70913 & 9.687414 & 14.43263 & 8.591500 & 2.020498 & 13.85621 & 4.624439 \\
Skewness & 1.233288 & 1.372922 & 0.696641 & -0.747020 & 1.375593 & -0.565228 & 1.564423 \\
Kurtosis & 4.405453 & 4.320960 & 2.792521 & 3.756438 & 5.887516 & 2.818859 & 5.675357 \\
Jarque-Bera & 108.8004 & 125.3420 & 26.78781 & 37.85880 & 214.7415 & 17.69503 & 228.7874 \\
Probability & 0.000000 & 0.000000 & 0.000002 & 0.000000 & 0.000000 & 0.000144 & 0.000000 \\
\hline Source: authors' processing. & & & & & &
\end{tabular}

Source: authors' processing. 
We test the hypothesis $(\mathrm{H})$ as follows and study the corresponding research question $(\mathrm{RQ})$.

The hypothesis test:

H1: The increase of the variables Debt, Exp, Ins, Ur, Int and Hc is associated with a downward trend for the bank branches.

RQ1: In which way do the results of the hypothesis test differ for the two groups of EU countries (eurozone and noneuro)?

Table 4 presents the linear regression between mortgage, rent, utility bills or hire purchase arrears (Debt), inability to face unexpected financial expenses (Exp), income insecurity (Ins), household consumption (Hc), unemployment rate (Ur), internet users (Int), and number of commercial bank branches (BB) for all EU countries (27 countries). Table 4 is relevant for establishing a statistically relevant linear relation $(p$-value $=0.0000)$ between BB and Exp, Hc, Ins, and Int. Another statistically relevant linear relation appears between BB and Ur ( $p$-value $=0.0493)$. The sign of the coefficients Exp and Int is negative, as expected. At the same time, considering the six variables, we observed that Exp, Hc, Ins, and Int can be determinant factors for BB. According to the model, we also observe that all variables are significant, with a probability less than $5 \%$ (except for the variable Debt). The standard errors have low values, indicating that the variables are significant, an aspect also verified through the correlations between the variables.

Table 4. The estimation of the parameters for the regression linear model (EU-ALL). Dependent Variable: BB.

\begin{tabular}{cc}
\hline Variable & Coefficient \\
\hline Debt & 0.001563 \\
Exp & $-0.512924^{* * *}$ \\
Hc & $1.063901^{* * *}$ \\
Ins & $4.069853^{* * *}$ \\
Int & $-1.019736^{* * *}$ \\
Ur & $0.529302^{*}$ \\
C & $168.3008^{* * *}$ \\
\hline & $\mathrm{R}^{2}=0.402816$ \\
& $\Delta \mathrm{R}^{2}=0.391512$ \\
\hline
\end{tabular}

Note. $\mathbf{R}^{2}=$ coefficient of determination; $\Delta \mathbf{R}^{2}=$ adjusted $\mathrm{R}^{2} ;{ }^{*} p<0.05 .{ }^{* * *} p<0.001$. Source: authors' processing.

Table 5 presents the paired correlations for bank branches (BB), mortgage, rent, utility bills or hire purchase arrears (Debt), inability to face unexpected financial expenses (Exp), income insecurity (Ins), household consumption (Hc), unemployment rate (Ur), and internet users (Int) for all EU countries (EU-ALL). We observed a weak correlation between Exp and BB (coef. $=-0.005912)$ and between BB and Hc (coef. $=0.068175)$ and a stronger correlation between BB and Ins (coef. $=0.341525$ ) (see Table 5). The strongest correlation appears between BB and Int (coef. $=0.362602)$. Therefore, the strongest correlation with $\mathrm{BB}$ is presented by the indicator internet users. This result is confirmed by other studies: Lassar et al. (2005), Floh and Treiblmaier (2006), Jayawardhena and Foley (2000) and Raza et al. (2020).

Even if the method of the least squares is one of the most known and used methods, it does not recognise the heterogeneous nature of the transversal sections. We will also use for a more precise analysis the linear models of the constant and random effects (Table 6). The first one estimates a common unique effect, while the second one offers an estimation by using an average of the distribution of the effects. 
Table 5. Correlation matrix of the variables BB, mortgage, rent, utility bills or hire purchase arrears (Debt), inability to face unexpected financial expenses (Exp), income insecurity (Ins), household consumption (Hc), unemployment rate (Ur), and internet users (Int) for EU-ALL.

\begin{tabular}{clllllll}
\hline & BB & Debt & Exp & Hc & Ins & Int & Ur \\
\hline BB & 1.000000 & & & & & & \\
Debt & -0.138038 & 1.000000 & & & & & \\
Exp & -0.005912 & 0.668934 & 1.000000 & & & & \\
Hc & -0.068175 & 0.566846 & 0.497874 & 1.000000 & & & \\
Ins & 0.341525 & 0.396370 & 0.455701 & 0.406250 & 1.000000 & & \\
Int & -0.362602 & -0.588635 & -0.489930 & -0.684517 & -0.267835 & 1.000000 & \\
Ur & -0.238831 & 0.515631 & 0.472757 & 0.469267 & 0.737183 & -0.281588 & 1.000000 \\
\hline
\end{tabular}

Source: authors' processing.

Table 6. The regression linear model (EU-ALL).

\begin{tabular}{ccc}
\hline Variable & $\begin{array}{c}\text { Coefficient } \\
\text { Fixed Effects }\end{array}$ & $\begin{array}{c}\text { Coefficient } \\
\text { Random Effects }\end{array}$ \\
\hline Debt & $-0.089262^{*}$ & -0.114309 \\
Exp & $-0.063192^{*}$ & -0.082112 \\
Hc & $-0.147839^{* *}$ & -0.231545 \\
Ins & $1.354364^{* * *}$ & $1.408221^{* * *}$ \\
Int & $-0.713221^{* * *}$ & $-0.719221^{* * *}$ \\
Ur & $-0.252707^{* *}$ & -0.174043 \\
C & $95.85910^{* * *}$ & $101.0622^{* * *}$ \\
\hline & $\mathrm{R}^{2}=0.942878$ & $\mathrm{R}^{2}=0.582636$ \\
\hline & $\Delta \mathrm{R}^{2}=0.936597$ & $\Delta \mathrm{R}^{2}=0.574736$ \\
\hline
\end{tabular}

Note. $\mathrm{R}^{2}=$ coefficient of determination; $\Delta \mathrm{R}^{2}=$ adjusted $\mathrm{R}^{2} ;{ }^{*} p<0.05 .{ }^{* *} p<0.01 .{ }^{* * *} p<0.001$. Source authors' processing.

To decide which model, the model with fixed effects or the model with random effects, is more suitable, we applied the Hausman test (Table 7). Using the test (Table 7), we compared the regression linear model for the fixed effects and the random effects and obtained a value smaller than $5 \%$ for $p$-value, meaning that we can accept the alternative hypothesis of a regression linear model with constant effects. Therefore, we focus on the analysis of the regression linear model with constant effects. Interpreting the results obtained from the estimation of the parameters for the regression linear model with fixed effects in Table 6, we conclude that the $p$-value is significant because all the variables of the model with fixed effects have values under $5 \%$ (except for the variable Debt). Ins and Int present values under 1\%, Hc and Ur present values under 1\%, while Exp presents values under $5 \%$. Only the variable Debt presents higher values. As highlighted by R-squared, these variables have an influence of $94 \%$. These indicators of mortgage, rent, utility bills or hire purchase arrears, (Debt), inability to face unexpected financial expenses (Exp), income insecurity (Ins), household consumption (Hc), unemployment rate (Ur), and internet users (Int) explain the $94 \%$ in the variation of the number of commercial bank branches (BB) and presents an estimation of success for the regression equation. Adjusted R-squared has a value of $93.6 \%$. The other $6.4 \%$ are the influence of other factors on the dependent variable (BB), which are not included in the model.

Table 7. Hausman test (EU-ALL).

\begin{tabular}{cccc}
\hline Test Summary & Chi-Sq. Statistic & Chi-Sq. d.f. & Prob. \\
\hline Cross-section random & 17.823522 & 6 & 0.0067 \\
\hline Source: authors' processing. & & &
\end{tabular}


The general linear regression equation is:

$$
Y=\beta_{0}+\beta_{1} X_{1}+\beta_{2} X_{2}+\ldots+\beta_{n} X_{n}
$$

where

$\mathrm{Y}$ is the dependent variable (BB)

$\beta_{0}, \beta_{1}, \beta_{2}, \ldots \beta_{n}=$ the coefficients

$\mathrm{X}_{\mathrm{o}}, \mathrm{X}_{1}, \mathrm{X}_{2}, \ldots \mathrm{X}_{\mathrm{n}}=$ are the independent variables (Debt, Exp, Ins, Hc, Ur, Int)

After applying the Hausman test (Table 7) and according to the fixed effects data in Table 6, it results that the variable Ins (1.35) has the strongest positive impact on BB, while the variable Int $(-0.71)$ has the strongest negative impact on BB. The signs of the coefficients Debt, Exp, Hc, Int, and Ur are negative, as expected. There is an opposite correlation between Int and BB. Thus, if Int decreases one point, BB approximately increases 0.71 points. We can also give the following interpretation: if Int increases one point, BB decreases 0.71 points. The result can be justified as follows: together with the increase of the number of internet users, the banking products based on this technology also developed (e.g., internet banking, mobile banking, etc.). These products are available 24/7, replacing the human activity. Therefore, the number of bank employees diminishes, and their work is replaced more and more by the computer technology based on the internet. Due to the diminishing of the human activity, many banks also closed territorial bank branches. At the present time, there are banks which no longer have territorial branches and their operations are exclusively performed through internet banking. These banks have major advantages from the point of view of the profitability. Other strong negative correlations appear between Ur and BB $(-0.25)$ and between Hc and BB $(-0.14)$. The sign of the coefficient $\mathrm{Ur}$ is negative, meaning that, if $\mathrm{Ur}$ increases one point, $\mathrm{BB}$ decreases 0.25 points.

One of the hypotheses of the classic model of linear regression is that heteroscedasticity does not exist. We will test the heteroscedasticity presence by using the BreuschPagan-Godfrey test. It tests if the variation between the regression errors depends on the independent variables' values. In this case, heteroscedasticity exists. We performed corrections by using a logarithm, and the outcome is presented in Table 8.

Table 8. Outcomes after the logarithm.

\begin{tabular}{lc}
\hline & Dependent Variable: LOG(BB) \\
\hline Variable & Coefficient \\
\hline LOG(Debt) & $-0.941490^{*}$ \\
LOG(Exp) & $-0.365633^{* * *}$ \\
LOG(Hc) & $-1.301586^{* * *}$ \\
LOG(Ins) & $0.134904^{* *}$ \\
LOG(Int) & $-2.152993^{* * *}$ \\
LOG(Ur) & $0.410911^{* * *}$ \\
\hline & $\mathrm{R}^{2}=0.362425$ \\
\hline \\
\hline
\end{tabular}

In the same time, considering that household consumption, unemployment rate, inability to face unexpected financial expenses, internet users and income insecurity are representative for well-being, we observed that these indicators can be determinant factors for the number of commercial bank branches per 100,000 adults. Thus, the hypothesis $\mathrm{H}$ is valid. 


\subsection{Eurozone and Noneuro Models}

Moreover, we intend to test if the results significantly differ for the eurozone countries compared to the noneuro countries. Thus, we try to answer to the question formulated at the beginning of the study.

RQ1: In which way do the results of the hypothesis test differ for the two groups of EU countries (eurozone and noneuro)?

Analysing Table 8, we observe important differences between the two groups of countries from the point of view of the correlations between the dependent variable and the independent variables. The sign is identical only for Ins and Int. For the eurozone countries, the strongest correlation is between $\mathrm{BB}$ and Ins (0.32); for the noneuro countries, the strongest correlation is between $\mathrm{BB}$ and $\mathrm{Hc}(0.58)$. We observe a negative correlation BB and Int for both groups. Comparing the data between Tables 5 and 9, we observe a similarity of the signs for all the indicators for EU-ALL and eurozone countries. Unlike these two groups, the group of noneuro countries is different from the point of view of the correlations between variables.

Table 9. Correlation matrix: BB, Debt, Exp, Ins, Hc, Ur and Int (eurozone countries and noneuro countries).

\begin{tabular}{|c|c|c|c|c|c|c|c|}
\hline \multicolumn{8}{|c|}{ Eurozone Countries } \\
\hline & BB & Debt & $\operatorname{Exp}$ & Hc & Ins & Int & Ur \\
\hline BB & 1.000000 & & & & & & \\
\hline Debt & -0.012684 & 1.000000 & & & & & \\
\hline Exp & -0.091235 & 0.605907 & 1.000000 & & & & \\
\hline $\mathrm{Hc}$ & -0.054373 & 0.520167 & 0.489591 & 1.000000 & & & \\
\hline Ins & 0.326444 & 0.453059 & 0.545366 & 0.467834 & 1.000000 & & \\
\hline Int & -0.319435 & -0.449431 & -0.343976 & -0.669964 & -0.384909 & 1.000000 & \\
\hline Ur & 0.238871 & 0.618939 & 0.556499 & 0.499084 & 0.736643 & -0.361641 & 1.000000 \\
\hline \multicolumn{8}{|c|}{ Non-Euro Countries } \\
\hline & BB & Debt & $\operatorname{Exp}$ & Hc & Ins & Int & Ur \\
\hline $\mathrm{Bb}$ & 1.000000 & & & & & & \\
\hline Debt & -0.590831 & 1.000000 & & & & & \\
\hline Exp & 0.237570 & 0.726577 & 1.000000 & & & & \\
\hline $\mathrm{Hc}$ & 0.582666 & 0.783226 & 0.617250 & 1.000000 & & & \\
\hline Ins & 0.377346 & 0.444315 & 0.464626 & 0.196857 & 1.000000 & & \\
\hline Int & -0.554608 & -0.761988 & -0.644315 & -0.833558 & -0.144273 & 1.000000 & \\
\hline $\mathrm{Ur}$ & -0.210663 & 0.542480 & 0.590281 & 0.377513 & 0.721607 & -0.279992 & 1.000000 \\
\hline
\end{tabular}

Source: authors' processing.

After applying the Hausman test (see Table 10), we compared the regression linear model between the fixed effects and the random effects and obtained a value under $5 \%$ for $p$-value, both for the eurozone countries $(3.05 \%)$ and the noneuro countries $(0.00 \%)$, meaning we accept the regression linear model with fixed effects. Thus, we will focus on the analysis of the regression linear model with fixed effects.

Table 10. The Hausman test (eurozone countries and noneuro countries).

\begin{tabular}{cccc}
\hline \multicolumn{4}{c}{ Eurozone Countries } \\
\hline Test Summary & Chi-Sq. Statistic & Chi-Sq. d.f. & Prob. \\
\hline Cross-section random & 13.925166 & 6 & 0.0305 \\
\hline \multicolumn{4}{c}{ Noneuro Countries } \\
\\
\hline Test Summary & Chi-Sq. Statistic & Chi-Sq. d.f. & Prob. \\
\hline Cross-section random & 69.477825 & 6 & 0.0000 \\
\hline Source: authors' processing. & & &
\end{tabular}


After interpreting the results from the estimation of the parameters for the regression linear model with fixed effects in Table 11, we conclude that, for the eurozone countries, the $p$-value is significant because three variables of the model with fixed effects present values under $0.1 \%$ (Hc, Ins, and Int). Exp and Ur present values under $1 \%$. Only the variable Debt presents higher values. As highlighted by R-squared, the variables have an influence of $96 \%$. The indicators for mortgage, rent, utility bills or hire purchase arrears (Debt), inability to face unexpected financial expenses (Exp), income insecurity (Ins), household consumption (Hc), unemployment rate (Ur), and internet users (Int) explain 96\% of the variation of the number of commercial bank branches and presents a successful estimation for the regression equation. Adjusted R-squared has a value of $95.5 \%$. The other $4.5 \%$ represents influence of other factors not included in the study on the dependent variable (BB). For the noneuro countries, the $p$-value is significant for the three variables (Ins, Int, Ur) of the model with fixed effects ( $p$-value has values under $0.1 \%$ ). Related to R-squared, the variables have an influence of $89 \%$. Adjusted R-squared has a value of $87.44 \%$. Thus, other factors not included in our model influence BB in a proportion of $12.56 \%$.

Table 11. The regression model (eurozone countries and noneuro countries).

\begin{tabular}{ccc}
\hline Variable & $\begin{array}{c}\text { Fixed Effects } \\
\text { Eurozone Countries }\end{array}$ & $\begin{array}{c}\text { Fixed Effects } \\
\text { Noneuro Countries }\end{array}$ \\
\hline Debt & $-0.075644^{* *}$ & -0.106361 \\
Exp & $-0.103370^{* * * *}$ & 0.012561 \\
Hc & $-0.253437^{* * *}$ & $0.748805^{* *}$ \\
Ins & $0.971400^{* * *}$ & $2.155640^{* * *}$ \\
Int & $-0.778512^{* * *}$ & $-0.583479^{* * *}$ \\
Ur & $-0.097985^{* *}$ & $-1.142040^{* * *}$ \\
C & $107.3486^{* * *}$ & 35.51999 \\
\hline & $\mathrm{R}^{2}=0.9600$ & $\mathrm{R}^{2}=0.891603$ \\
\hline
\end{tabular}

Note. $\mathrm{R}^{2}=$ coefficient of determination; $\Delta \mathrm{R}^{2}=$ adjusted $\mathrm{R}^{2} ;{ }^{* *} p<0.01 .{ }^{* * *} p<0.001$. Source: authors' processing.

We tested the heteroscedasticity presence by using the Breusch-Pagan-Godfrey test. We observed that heteroscedasticity exists. We performed corrections by using a logarithm, and the outcomes are presented in Table 12.

Table 12. Outcomes after the logarithm.

\begin{tabular}{ccc}
\hline Variable & $\begin{array}{c}\text { Eurozone Countries } \\
\text { Coefficient }\end{array}$ & $\begin{array}{c}\text { Noneuro Countries } \\
\text { Coefficient }\end{array}$ \\
\hline LOG(Debt) & $-0.243089^{* * *}$ & $-0.100155^{* * *}$ \\
LOG(Exp) & $-0.283081^{* *}$ & $-0.562069^{* * *}$ \\
LOG(Hc) & $-1.774652^{* * *}$ & $-3.099890^{* * *}$ \\
LOG(Ins) & $0.136218^{*}$ & $0.260245^{* * *}$ \\
LOG(Int) & $-2.580537^{* * *}$ & $-0.646504^{* * *}$ \\
LOG(Ur) & $0.604940^{* * *}$ & $-0.056396^{*}$ \\
\hline & $\mathrm{R}^{2}=0.416056$ & $\mathrm{R}^{2}=0.681644$ \\
& $\Delta \mathrm{R}^{2}=0.400203$ & $\Delta \mathrm{R}^{2}=0.660182$ \\
\hline
\end{tabular}

Note. $\mathrm{R}^{2}=$ coefficient of determination; $\Delta \mathrm{R}^{2}=$ adjusted $\mathrm{R}^{2} ;{ }^{*} p<0.05$. ${ }^{* *} p<0.01 .{ }^{* * *} p<0.001$. Source: author's processing.

Next, we used Equation (2) for both groups of countries (eurozone countries and noneuro countries). To find answers for $R Q$, we also used data from Table 12. According to the data in Table 12 for eurozone countries, the variable Ur $(0.60)$ has the strongest positive impact on $\mathrm{BB}$ and the variable Int $(-2.58)$ has the strongest negative impact on BB. The signs of the coefficients Debt, Exp, Hc and Int are negative, as expected. There is a reverse correlation between Int and BB. If Int grows by one point, BB diminishes with 
2.58 points As regards the noneuro countries, $\mathrm{Hc}(-3.099)$ has the most significant negative impact over BB. Also, considering that household consumption, income insecurity and Internet users are representative for well-being, we observed that they can be determinant factors for the evolution of the indicator of the number of commercial bank branches per 100,000 adults. Therefore, the hypothesis $\mathrm{H}$ is valid.

Worth to mention is the Ur coefficient value to the two groups of countries: 0.604940 to eurozone countries and -0.056396 to noneuro countries. It means that it negatively impacts a group of countries and positively impacts the other group of countries. To answer our research question $(\mathrm{RQ})$, we can conclude that the impact of the well-being components on the number of commercial bank branches is very different for the eurozone countries compared to the noneuro countries.

\section{Discussion}

Using the same variables and coefficients for all the country groups, we observe a change in the behaviour of the independent variables. We can observe that for all three models, coefficient signs match five out of six variables (Debt, Exp, Hc, Ins, Int).

The Ur variable sign differs on Noneuro countries compared to the other groups EU-ALL and eurozone countries. The variable with the lowest coefficient for eurozone countries is Int, and for noneuro countries is Hc.

By separating the countries in groups (eurozone countries and noneuro countries) and comparing the results with the major group (EU-ALL), we observe a similarity in the evolution of the indicators (the signs of the coefficients also coincide) for EU-ALL and the eurozone countries. Therefore, the group of eurozone countries is a dominant group in EU-ALL. This affirmation is also supported by the number of countries in this group (19) compared to the number of countries using the national currency (8). Variable Int has the most significant negative impact on EU-ALL and eurozone countries, which means that a $1 \%$ increase of Int will lead to a $2.15 \%$ decrease of BB for EU-ALL and $2.58 \%$ for eurozone countries. The Hc variable has the most significant negative impact on $\mathrm{BB}$ when speaking of noneuro countries: a 1\% increase of Hc will lead to a 3.09\% decrease of BB indicator. At the same time, the influence of the six variables selected for our research is strong, explained by high value of R-squared for all three groups of countries. Prob (F-statistic) is suitable for all the three models corresponding to the three groups of countries. In conclusion, we can state that the hypothesis $\mathrm{H}$ is valid for all EU countries, but the impact of the well-being components on $\mathrm{BB}$ is significantly stronger for the Noneuro countries $($ R-squared $=0.68)$ than for the eurozone countries $(R$-squared $=0.41)($ please, see Table 13$)$. Other authors support this idea, as presented in Section 2: Reinhart and Rogoff (2011), Kapoor et al. (2007), Staikouras and Wood (2004), Chunguang et al. (2019), Popa (2019), Cvetkoska and Savić (2017).

Table 13. Synthesis.

\begin{tabular}{cccc}
\hline Variable & \multicolumn{3}{c}{ Coefficient } \\
\cline { 2 - 4 } & EU-ALL & Eurozone Countries & Noneuro Countries \\
\hline LOG(Debt) & $-0.941490^{*}$ & $-0.243089^{* * *}$ & $-0.100155^{* *}$ \\
LOG(Exp) & $-0.365633^{* * *}$ & $-0.283081^{* *}$ & $-0.562069^{* * *}$ \\
LOG(Hc) & $-1.301586^{* * *}$ & $-1.774652^{* * *}$ & $-3.099890^{* * *}$ \\
LOG(Ins) & $0.134904^{* *}$ & $0.136218^{*}$ & $0.260245^{* * *}$ \\
LOG(Int) & $-2.152993^{* * *}$ & $-2.580537^{* * *}$ & $-0.646504^{* * *}$ \\
LOG(Ur) & $0.410911^{* * *}$ & $0.604940^{* * *}$ & $-0.056396^{*}$ \\
\hline $\mathrm{R}^{2}$ & $0.362425^{* * *}$ & 0.416056 & 0.681644 \\
\hline
\end{tabular}

Note. $R^{2}=$ coefficient of determination; ${ }^{*} p<0.05 .{ }^{* *} p<0.01$. ${ }^{* * *} p<0.001$. Source: authors' processing. 
The coronavirus cases registered in 2020 have started to produce significant effects on the macroeconomic indicators in all countries. Implicitly, they will also impact the bank systems, not as direct influence, but rather in an indirect way, through the modification of other factors in close connections to BB, including the indicators specific to well-being. These aspects raise a question about the multitude of external factors not considered in our models, which could impact and influence the evolution of BB in the future.

\section{Conclusions}

The study is based on situations from 27 countries (EU member states), with various economic and fiscal policies; 19 countries are eurozone countries, while eight countries are noneuro countries.

Starting in 2008 (the beginning of the economic crises in Europa) and due to the decrease of bank profitability in all countries, the banks have tried to streamline their activity by reducing the number of employees and bank branches. Thus, a downward trend of the bank branches indicator (BB) manifested in all countries (eurozone and noneuro) in the period 2008-2019. There is no difference in the evolution of this indicator in the noneuro countries (considering the specificity of the national currencies and their management by the states) and in the eurozone countries.

The study implies the fact that the BB evolution is influenced by many factors, already analysed in several scientific studies. Among the macroeconomic indicators, the authors concentrate on mortgage, rent, utility bills or hire purchase arrears (Debt), inability to face unexpected financial expenses (Exp), income insecurity (Ins), household consumption (Hc), unemployment rate (Ur), and internet users (Int). The study contains a comparison between the results of the regression model for the eurozone countries and noneuro countries and the similarities with EU-ALL; the synthesis is presented in Chapter 4. We conclude that the cumulated impact of the well-being indicator on BB is significantly stronger for the noneuro countries $(R$-squared $=0.68)$ than for the eurozone countries $(R$-squared $=0.41)$.

Our findings in this study confirm that out of the six analysed factors, four of them overwhelmingly influence the number of commercial banking subsidiaries for 100,000 adults:

1. Internet users (Int). Households' internet access positively influences banking activity and, implicitly, banking systems because potential clients are more comfortable approaching and can benefit from internet banking advantages. Household welfare also depends on free time and the possibility of paying, open accounts, getting support or cash out in real-time, which supports the increase of this indicator's value and life quality. The new digital technologies, almost limitlessly accessed by the population and at lower costs, automate an essential part of financial services, facilitating fresh and profitable banking product creation, portfolio advice, and payment systems (Vives 2017). The advantages of a good relation between internet users and banks are, from the banks' perspective, as follows: reducing costs, obtaining new clients, efficacy, and the possibility to improve the reputation of both clients and potential clients. (Jayawardhena and Foley 2000). Online banking services bring satisfaction for both the clients and the bank and represent a contemporaneous reality (Raza et al. 2020).

2. Incapacity of dealing with unexpected financial expenses (Exp). It is easy to outline that the banking system's evolution depends on its profitability. A bank's profitability is influenced not only by the bank's internal managerial decisions but also by external factors, more precisely the weak saving tendency of the population, the accumulation of debts, and, implicitly, the use or nonuse of banking services. Staikouras and Wood (2004) support this idea too. Households' loans also influence the evolution of banking systems, a matter noted by the authors Smith et al. (2003).

3. Household consumption ( $\mathrm{Hc}$ ). The lack of welfare, the burden of debt, loans rate, and household consumption diminution are key elements at the foundation of banking losses with a direct effect on banking systems' evolution. Studies mention that house- 
holds' consumption and financial vulnerability are decisive factors for banking losses (Pesola 2005).

4. Income insecurity (Ins). Income insecurity caused by labour market fluctuations may generate credit risk and it will implicitly affect the bank activity-an idea supported by Chunguang et al. (2019), who presented a complex relationship between the income insecurity indicator and the banking systems.

During the research, the authors concentrated mostly on the influence of the wellbeing indicators on the bank systems. This aspect was confirmed by the studies presented in Section 2. Still, we did not take in consideration the combination of the macroeconomic factors with the noneconomic factors. Therefore, we consider necessary to include other factors in a future research, such as legislative factors, social factors, behavioural factors, and other noneconomic crucial factors, to obtain a more significant model (e.g., political stability, speed in the modification of the legislation, corruption, the shadow economy, etc.).

This research approach's uniqueness is evident, considering both the approached topic together with the method used and the selection of indicators whose evolution or involution was presented in the paper. According to the mentioned bibliographical resources, the indicators categories with which the authors worked in their process constitute an original initiative, tackled very little in this context or divided into distinct parts, as illustrated in the article. This scientific material constitutes an innovative contribution in the field, which can be used to document further studies and for indicators and concepts study.

Author Contributions: Conceptualization, I.C.I.; methodology, I.C.I. and L.-L.D.; software, I.C.I.; validation, I.C.I. and L.-L.D.; formal analysis, I.C.I.; resources, L.-L.D.; data curation, L.-L.D.; writingoriginal draft preparation, I.C.I.; writing-review and editing, I.C.I.; visualization, L.-L.D.; supervision, I.C.I. All authors have read and agreed to the published version of the manuscript.

Funding: This research received no external funding.

Conflicts of Interest: The authors declare no conflict of interest.

\section{References}

Alatartseva, Elena, and Galina Anzelmovna Barysheva. 2016. What is well-being in the modern society: Objective view. In SHS Web of Conferences. Vol. 28: Research Paradigms Transformation in Social Sciences (RPTSS)—Les Ulis. Tomsk: EDP Sciences, vol. 282015.

Aldasoro, Inaki, Ingo Fender, Bryan Hardy, and Nikola Tarashev. 2020. Effects of Covid-19 on the Banking Sector: The Market's Assessment; BIS Bulletins 12. Bank for International Settlements. Available online: https:/ /www.bis.org/publ/bisbull12.pdf (accessed on 4 January 2021).

Al-Sharafi, M. Abdullah, R. Abdullah Arshah, A. Fadi Herzallah, and Qasim Alajmi. 2017. The effect of perceived ease of use and usefulness on customers intention to use online banking services: The mediating role of perceived trust. International Journal of Innovative Computing 7. [CrossRef]

Avery, B. Robert, Raphael Bostic, S. Paul Calem, and Glenn Canner. 1999. Consolidation and bank branching patterns. Journal of Banking and Finance 23: 497-532. [CrossRef]

Barrell, Ray, E. Philip Davis, and Olga Pomerantz. 2006. Costs of financial instability, household-sector balance sheets and consumption. Journal of Financial Stability 2: 194-216. [CrossRef]

Barros, Pedro. 1999. Multimarket competition in banking, with an example from the Portuguese market. International Journal of Industrial Organization 17: 335-52. [CrossRef]

Batishcheva, Galina Andreevna, Mikhail Yurevich Denisov, Irina Vladimirovna Rybchinskaya, and Mikhail Borisovich Stryukov. 2017. Influence of Social and Economic Development of the Region on the Functioning of the Regional Banking System. European Research Studies Journal 20: 490-99. [CrossRef]

Benvenuto, Marco, Alexandru Avram, Francesco Vincenzo Sambati, Marioara Avram, and Carmine Viola. 2020. The Impact of Internet Usage and Knowledge-Intensive Activities on Households' Healthcare Expenditures. International Journal of Environmental Research and Public Health 17: 4470. [CrossRef]

Berge, Tor Oddvar, and Katrine Godding Boye. 2007. An analysis of banks' problem loans. Economic Bulletin 178: 65-76.

Bergendahl, Goran, and Ted Lindblom. 2007. Pricing of Payment Services: A Comparative Analysis of Paper-based Banking and Electronic Banking. The Service Industries Journal 27: 687-707. [CrossRef]

Berger, Allen N., John H. Leusner, and John J. Mingo. 1997. The efficiency of bank branches. Journal of Monetary Economics 40: 141-62. [CrossRef]

Bernanke, Ben. 1983. Nonmonetary Effects of the Financial Crisis in the Propagation of the Great Depression. The American Economic Review 73: 257-76. 
Bernini, Cristina, and Paola Brighi. 2018. Bank branches expansion, efficiency, and local economic growth. Regional Studies 52: $1332-45$. [CrossRef]

Bloom, Nicholas, Max Floetotto, Nir Jaimovich, Itay Saporta-Eksten, and Stephen J. Terry. 2012. Really Uncertain Business Cycles (No. w18245). National Bureau of Economic Research. Available online: http:/ /www.nber.org/papers/w18245 (accessed on 26 January 2021).

Bloom, Nicholas. 2009. The impact of uncertainty shocks. Econometrica 77: 623-85.

BNR Report. 2020. The Report on the Financial Stability, June 2020 Anul V (XV), nr. 9 (19) Serie nouă. Available online: https: / / www.bnr.ro/PublicationDocuments.aspx?icid=19966 (accessed on 15 December 2020).

Camanho, Ana S., and Robert G. Dyson. 1999. Efficiency, size, benchmarks and targets for bank branches: An application of data envelopment analysis. Journal of the Operational Research Society 50: 903-15. [CrossRef]

Cauia, Alexandr. 2020. Securitatea financiară-Componentă fundamentală a securității naționale. Studii Juridice Universitare 49: $32-42$.

Cecchetti, Stephen G., Marion Kohler, and Christian Upper. 2009. Financial Crises and Economic Activity. NBER Working Paper, 15379. [CrossRef]

Chai, Bobby Boon-Hui, See Tan Pek, and Shong Goh Thian. 2016. Banking services that influence the bank performance. Procedia-Social and Behavioral Sciences 224: 401-7. [CrossRef]

Chunguang, Bai, Shi Baofeng, Liu Feng, and Joseph Sarkis. 2019. Banking credit worthiness: Evaluating the complex relationships. Omega 83: 26-38.

Comerton-Forde, Carole, Edwin Ip, David Ribar, James Ross, Nicolas Salamanca, and Sam Tsiaplias. 2018. Using survey and banking data to measure financial wellbeing. In Commonwealth Bank of Australia and Melbourne Institute Financial Wellbeing. Scales Technical Report 1. Victoria: The University of Melbourne.

Cvetkoska, Violeta, and Gordana Savić. 2017. Efficiency of bank branches: Empirical evidence from a two-phase research approach. Economic Research-Ekonomska Istraživanja 30: 318-33. [CrossRef]

Damar, Evren. 2007. Does Post-Crisis Restructuring Decrease the Availability of Banking Services? The Case of Turkey. Journal of Banking and Finance 31: 2886-905. [CrossRef]

Diener, Ed, Shigehiro Oishi, and Richard E. Lucas. 2003. Personality, culture, and subjective well-being: Emotional and cognitive evaluations of life. Annual Review of Psychology 54: 403-25. [CrossRef] [PubMed]

Dow, Sheila. 2012. Uncertainty-Denial. Department Discussion Paper DDP1204; University of Victoria. Available online: https: / / citeseerx.ist.psu.edu/viewdoc/download?doi=10.1.1.410.3339\&rep=rep1\&type=pdf (accessed on 12 January 2021).

Drehmann, Mathias, Marc Farag, Nikola Tarashev, and Kostas Tsatsaronis. 2020. Buffering Covid-19 Losses-the Role of Prudential Policy (No. 9); Bank for International Settlements. Available online: https://www.bis.org/publ/bisbull09.pdf (accessed on 10 January 2020).

Eurostat Statistical Reports. 2017. Final Report of the Expert Group on Quality of Life Indicators, 2017 ed. Available online: https: / / ec.europa.eu/eurostat/documents/7870049/7960327/KS-FT-17-004-EN-N.pdf/f29171db-e1a9-4af6-9e96-730e7e11e02f (accessed on 2 February 2021).

Eurostat-European Statistics. 2020. Quality of Life Indicators-Economic Security and Physical Safety. Available online: https: / / ec.europa.eu/eurostat/statistics-explained/index.php?title=Quality_of_life_indicators_-_economic_security_and_physical_ safety\#Economic_security (accessed on 30 October 2020).

Floh, Arne, and Horst Treiblmaier. 2006. What keeps the e-banking customer loyal? A multigroup analysis of the moderating role of consumer characteristics on e-loyalty in the financial service industry. Journal of Electronic Commerce Research 7. [CrossRef]

Frey, Bruno S., and Alois Stutzer. 2000. Happiness, economy and institutions. The Economic Journal 110: 918-38. [CrossRef]

Frey, Bruno, and Alois Stutzer. 2002. What can Economists Learn from Happiness Research? Journal of Economic Literature 40: 402-35. [CrossRef]

Frøyland, Esped, and Kai Larsen. 2002. How Vulnerable Are Financial Institutions to Macroeconomic Changes? An Analysis Based on Stress Testing; Economic Bulletin 3/2002. Norges Bank. Available online: https://norges-bank.brage.unit.no/norges-bank-xmlui/ handle/11250/2504526 (accessed on 4 January 2021).

Galati, Antonino, Maria Crescimanno, Salvatore Tinervia, and Francesco Fagnani. 2017. Social media as a strategic marketing tool in the Sicilian wine industry: Evidence from Facebook. Wine Economics and Policy 6: 40-47. [CrossRef]

Gathergood, John. 2012. Debt and Depression: Causal Links and Social Norm Effects. The Economic Journal 122: 1094-114. [CrossRef]

Gilchrist, Simon, Jae W. Sim, and Egon Zakrajšek. 2014. Uncertainty, financial frictions, and investment dynamics. National Bureau of Economic Research, w20038. [CrossRef]

Hannan, Timothy, and Gerald Hanweck. 2008. Recent Trends in the Number and Size of Bank Branches: An Examination of Likely Determinants. Finance and Economics Discussion Series 2008-02. Board of Governors of the Federal Reserve System (U.S.). FEDS Working Paper No. 2008-02. Available online: http:/ / dx.doi.org/10.2139/ssrn.1327057 (accessed on 5 January 2021).

Iuga, Iulia, and Anastasia Mihalciuc. 2020. Economic Crises. Effects on Banking Systems and Investment Decision. Berlin: LAP Lambert Academic Publishing, ISBN 978-620-2-92090-2.

Jayawardhena, Chanaka, and Paul Foley. 2000. Changes in the Banking sector-The case of Internet banking in UK. Electronic Networking Application and Ploicy 10: 19-30. [CrossRef]

Kapoor, John R., L.R. Dlabay, and Robert J. Hughes. 2007. Business and Personal Finance. New York: McGraw-Hill. 
Kassani, Sara Hosseinzadeh, Peyman Hosseinzadeh Kassani, and Seyed Esmaeel Najafi. 2018. Introducing a hybrid model of DEA and data mining in evaluating efficiency. Case study: Bank Branches. Academic Journal of Research in Economics and Management 3: 72-80.

Katona, George. 1975. Psychological Economics. New York: Elsevier.

Kaur, Simarpreet, and Sangeeta Arora. 2020. Role of perceived risk in online banking and its impact on behavioral intention: Trust as a moderator. Journal of Asia Business Studies 15: 1-30. [CrossRef]

Kowalczyk-Rólczyńska, Patrycja, and Tomasz Rólczyński. 2020. Logistic regression in the analysis of unexpected household expenses: Cross-country evidence. Journal of International Studies 13: 216-30. [CrossRef]

Lassar, Walfried M., Chris Manolis, and Sharon S. Lassar. 2005. The relationship between consumer innovativeness, personal characteristics, and online banking adoption. International Journal of Bank Marketing 23: 176-99. [CrossRef]

MacKerron, George. 2012. Happiness Economics from 35,000 Feet. Journal of Economic Surveys 26: 705-35. [CrossRef]

Mamonov, Mikhail. 2011. The impact of the crisis on the profitability of the Russian banking sector. Banking 12: 15-27.

Montagnoli, Alberto, and Mirko Moro. 2018. The Cost of Banking Crises: New Evidence from Life Satisfaction Data. Kyklos 71: 279-309. [CrossRef]

Montagnoli, Alberto, and Mirko Moro. 2014. Everybody Hurts Banking Crises and Individual Wellbeing. Working Paper. Sheffield: Department of Economics, University of Sheffield, ISSN 1749-8368.

Moutinho, Luiz, and Paul Phillips. 2002. The impact of strategic planning on the competitiveness, performance and effectiveness of bank branches: A neural network analysis. International Journal of Bank Marketing 20: 102-10. [CrossRef]

Muir, Kristy, Myra Hamilton, Jack Noone, Axelle Marjolin, and Fanny Salignac. 2017. Exploring Financial Wellbeing in the Australian Context. Sydney: Centre for Social Impact and Social Policy Research Centre-University of New South Wales Sydney, for Financial Literacy Australia.

Nagorny, Pavlo. 2020. Bank without Branches: Digitalization of Society and Fintech Technologies of the Present and Future. Accounting and Finance 89: 55-59. [CrossRef]

Neely, Andy, John Mills, Ken Platts, Huw Richards, Mike Gregory, Mike Bourne, and Mike Kennerley. 2000. Performance measurement system design: Developing and testing a process-based approach. International Journal of Operations E Production Management 20: 1119-45.

Oral, Muhittin, and Reha Yolalan. 1990. An empirical study on measuring operating efficiency and profitability of bank branches. European Journal of Operational Research 46: 282-94. [CrossRef]

Paradi, Joseph C., and Haiyan Zhu. 2013. A survey on bank branch efficiency and performance research with data envelopment analysis. Omega 41: 61-79. [CrossRef]

Pavlou, Paul, Huigang Liang, and Yajiong Xue. 2007. Understanding and mitigating uncertainty in online Relationships: A principalagent perspective. MIS Quarterly 31: 105-36. [CrossRef]

Pesola, Jarmo. 2005. Banking Fragility and Distress: An Economic Study of Macroeconomic Determinants. Research Discussion Paper 13. Helsinki: Bank of Finland.

Popa, Dan. 2019. Digitalizăm cu viteză maximă, dar în zonele rurale băncile au o prezență simbolică. De ATM-uri nici nu poate fi vorba. Hotnews.ro Finance-Banks Section. Available online: https://economie.hotnews.ro/stiri-finante_banci-23311057-digitalizamviteza-maxima-dar-zonele-rurale-bancile-prezenta-simbolica-atm-uri-nici-nu-poate-vorba.htm (accessed on 5 November 2020).

Prawitz, Aimee, E. Thomas Garman, Benoit Sorhaindo, Barbara O’Neill, Jinhee Kim, and Patricia Drentea. 2006. Incharge financial distress / financial well-being scale: Development, administration, and score interpretation. Journal of Financial Counseling and Planning 17: 2239338.

Putica, Maja. 2020. Influence of digital banking channels on the number of branches in European Union countries and Serbia. The Annals of the Faculty of Economics in Subotica 56: 67-84. [CrossRef]

Raza, Syed, Amna Umer, Muhammad Qureshi, and Abdul Dahri. 2020. Internet banking service quality, e-customer satisfaction, and loyalty: The modified e-SERVQUAL model. The TQM Journal 32: 1443-66. [CrossRef]

Reinhart, Carmen M., and Kenneth S. Rogoff. 2011. From financial crash to debt crisis. American Economic Review 101: 1676-706. [CrossRef]

Schaffnit, Claire, Rosen Dan, and C. Paradi Joseph. 1997. Best practice analysis of bank branches: An application of DEA in a large Canadian bank. European Journal of Operational Research 98: 269-89. [CrossRef]

Smith, Rosie, Christos Staikouras, and Geoffrey Wood. 2003. Non-interest income and total income stability. Cass Business School Research Paper. [CrossRef]

Staikouras, Christos K., and Geoffrey E. Wood. 2004. The determinants of European bank profitability. International Business $\mathcal{E}$ Economics Research Journal (IBER) 3. [CrossRef]

Stiglitz, Joseph E., Amartya Sen, and Jean-Paul Fitoussi. 2009. Report by the Commission on the Measurement of Economic Performance and Social Progress. Available online: https:/ /www.researchgate.net/publication/258260767_Report_of_the_Commission_on_the_ Measurement_of_Economic_Performance_and_Social_Progress_CMEPSP (accessed on 29 January 2021).

Tonzer, Lena. 2017. Uncertainty, Financial Crises, and Subjective Well-Being. IWH Discussion Papers No. 2. Saale: Leibniz-Institut für Wirtschaftsforschung Halle (IWH).

Vassiloglou, Myrto, and Demetrios Giokas. 1990. A study of the relative efficiency of bank branches: An application of data envelopment analysis. Journal of the Operational Research Society 41: 591-97. [CrossRef] 
Vives, Xavier. 2017. The impact of FinTech on banking. European Economy 2: 97-105.

Zenios, Christiana V., Stavros A. Zenios, Kostas Agathocleous, and Andreas C. Soteriou. 1999. Benchmarks of the efficiency of bank branches. Interfaces 29: 37-51. [CrossRef]

Zingales, Luigi. 2011. The Role of Trust in the 2008 Financial Crisis. The Review of Austrian Economics 24: 235-49. [CrossRef] 